\title{
SOME ENVIRONMENTAL PARAMETERS AFFECTING SWEET PEPPER GROWTH AND PRODUCTIVITY UNDER DIFFERENT GREENHOUSE FORMS IN HOT AND HUMID CLIMATIC CONDITIONS
}

\author{
Abd-El-Baky, H. M. ${ }^{1}$; S. A. Ali ${ }^{2}$; Z. El Haddad ${ }^{2}$ and Z. A. El Ansary ${ }^{2}$ \\ ${ }^{1}$ Agric. Eng. Research Institute, ARC., Dokky, Giza. \\ 2 Agric. Eng. Dept., Fac. Agric., Moshtohor, Toukh, Qalubia, P.O. Box, \\ 13736, Egypt. Phone: +2 $0132467034 \quad$ Fax: +2 0132467786 \\ E-Mail samirali66@yahoo.com
}

\begin{abstract}
The influence of environmental parameters on growth rate, fresh yield, and irrigation performance of color sweet pepper (Capsicum annuum var annuum cv.) were studied in three different types of greenhouse forms. The three different systems are; gable-even-span form, flat roof net-house, and modified Quonset greenhouse during 2002/2003 seasons. Diurnal external and internal, air temperature, air relative humidity, vapour pressure deficit (VPD), and light intensity were measured to analysis their correlation with sweet pepper crop yield response. The plants were periodically collected throughout their growth cycles to measure vegetative, flowering and yields. For irrigation performance test three indicators were determined; annual relative irrigation supply (ARIS), irrigation water use efficiency (IWUE), and annual water productivity (AWP). The obtained results showed that, the gable-even-span greenhouse (fully controlled) gave the best growth rate between vegetative and generative parts of the plant as compared with other systems. The greatest plant height $(7.7 \mathrm{~cm} /$ week) achieved during autumn season for the three different greenhouse forms. While, the plant height rates during winter season for the three different greenhouse forms, respectively, were $5.8,1.8$ and $4.0 \mathrm{~cm} /$ week. The obtained data also revealed that the leaf area index (LAI) for the three different forms was $6.16,2.23$, and 2.44 , respectively. Therefore, the greatest fresh yield and quality of sweet pepper were achieved by gable-even-span form (fully controlled greenhouse) as compared with other forms of greenhouse. Mean annual irrigation supply (ARIS) values were slightly up to 1 for the three different forms. Mean irrigation water use efficiency (IWUE) values for the three different forms ranged from 3.98 to $9.75 \mathrm{~kg} / \mathrm{m}^{3}$, while (AWP) in the fully controlled greenhouse was higher than 3.18 and 4.08 times from flat roof net-house and modified Quonset, respectively due to increase the irrigation water use efficiency (IWUE) and high value of yield grown off-season.
\end{abstract}

\section{INTRODUCTION}

Organisms such as plants grow as a result of the influence of their genetics and their environment consisting of physical, chemical and biological factors. One aspect of this environment is physical micro-environment, or microclimate (Boonen et al., 2000). Color sweet pepper is one of the important five high valuable crops in greenhouses (intensive crop production).

World total pepper production reaching over 24 million tons every year for both, chili pepper and sweet pepper (Faostat, 2005) 
Abd-El Baky, H.M. et al.

The greenhouse has been used in various forms for centuries as a means of protecting plants from extremes of weather, enabling, e.g. exotic tropical species to be grown at higher latitudes. This is achieved by creating better growing conditions, traditionally by maintaining a higher internal ambient, compared with external ambient temperature. Greenhouse cultivation is steadily growing agricultural sector all over the world (Enoch and Enoch, 1999 and Von Eslner et al. 2000 ).The land area devoted to greenhouses production of color sweet peppers has been increased substantially over the past decade. Spain, Israel and the Netherland are considered the first three countries leading in sweet pepper production in the world under different plant-house systems it reached to 8600,1700 and 1200 hectares, respectively. While in Egypt it reached to 400 hectares with total plant-houses area of 11,300 hectares. Also pepper production differed due to the different environmental and management systems, where it ranged from 5 to $28.8 \mathrm{~kg} / \mathrm{m}^{2}$ and export percentage ranged from 50 to $90 \%$ (Jovicich et al., 2003 ; Abdelbaky, 2006 ; Dahesh, 2007 ; De Swart, 2007 ; and Jacques, 2007).

There are three main plant-house types currently in use. In modern agricultural technologies introduced constructions that can be divided into 3 main groups: Net-houses (screen-house), Tunnels (traditional Egyptian house) and fully controlled greenhouses (Critten and Bailey, 2002 and Eleazer 2006). The environmental parameters that affect plant growth inside the greenhouses are; air temperature, light intensity, air relative humidity, carbon dioxide concentration, air speed, and root media (Georgios, 2001).

Greenhouse climate management can be significantly improved by implementing advanced controllers designed by using optimal control theory (Van Henten, 1994; Tap, 2000 and Graaf and reinhard, 2006). The performance improvements mainly concern is energy efficiency and profit. Another important advantage of optimal controllers is their small number of settings which are very transparent. The performance improvements realized by optimal plant-house climate controllers relate to the explicit detailed quantitative scientific knowledge they exploit. This knowledge concerns the behavior of the crop in relation to the plant-house climate and the behavior of the crop in relation to the outside weather conditions and the controls (Van Ooteghem, 2007).

Development and flowering of plants relates to root zone and air temperature (Khah and Passam 1992), and control of temperature is important tool of crop growth (De Koning 1996). The optimum temperature is determined by the process involved in the utilization of assimilate products of photosynthesis, i.e. distribution of dry matter to shoots, leaves, roots, and fruit. For control of crop growth, average temperature over one or several days in more important than the day/night temperature differences (Bakker 1989 , De Koning 1996). This average temperature is also referred to as the 24 hour average temperature or 24-hour mean temperature (Bakker 1989 and Portree 1996). Night temperature over $21^{\circ} \mathrm{C}$ and day temperatures as high as $38^{\circ} \mathrm{C}$ caused flower abortion ( Rylski, 1986 an Elio Jovicich et al. 2003). 
Optimum photosynthesis occurs between 21 to 22 C (Portree,1996), this temperature serves as the target for managing temperature during the day when the photosynthesis occurs. Optimum temperature for vegetative growth for greenhouses peppers is between 21 to $23^{\circ} \mathrm{C}$ with the optimum temperature for yield about $21^{\circ} \mathrm{C}$ (Bakker, 1989). Fruit set, however, is determined by the 24-hour mean temperature and the difference in day-night temperature, with the optimum night temperature for flowering and fruit setting at 16 to $18^{\circ} \mathrm{C}$ (Pressman et al., 1998). Target 24-hour temperatures for the main greenhouse vegetable crops (cucumber, tomatoes, peppers) can vary from crop to crop with differences even between cultivars of the same crop, the standard temperature for sweet pepper under Dutch greenhouse (day/night 16.h/8.h) was 21.1/18.6 and 21.2/18.7 C (De swart 2007).

Zabri and Burrage (1997) stated that, the concept of vapor pressure difference or vapor pressure deficit (VPD) can be used to establish set-points for air temperature and relative humidity in combination to optimize transpiration under any given light level, and VPD is one of the important environmental factors influencing the growth and development of greenhouse crops. Since the principles of VPD can be used to control the transpiration rate, there is a range of optimum VPDs corresponding to optimum transpiration rates for maximum sustained yield. Portree (1996) found that, the optimum range of VPD is between 3 to $7 \mathrm{grams} / \mathrm{m}^{3}$ ( 3.9 to $9.2 \mathrm{mb}$ ). According to Rylski and Spigeman (1986) both high VPD $\left(>2 \mathrm{kP}_{\mathrm{a}}\right)$ and Low VPD $\left(<0.2 \mathrm{kP}_{\mathrm{a}}\right)$, influence the growth rate of protected cropping, while Prenger and Ling (2004) reported that the disease infection is most increased below 0.03 Psi $\left(0.2 \mathrm{kP}_{\mathrm{a}}\right)$.

Kittas (1999) reported that, the photo-synthetically active radiation (PAR) in the range of $0.4-0.7 \mu \mathrm{m}$ waveband received more attention the other wavebands of wavelengths of the solar spectrum because of its fundamental role in photos-synthesis. However the total solar spectrum is measured with a pyranometers in units of watts $/ \mathrm{m}^{2}$ relating to light in the 0.4 to $1.1 \mu \mathrm{m}$ wavelength. All plants show a peak of light use in the red region, approximately $650 \mathrm{~nm}$ and smaller peak in the blue region at approximately $0.450 \mu \mathrm{m}$ (Salisbury and Ross 1978). Plants are relatively inefficient at using light and are only able to use about a maximum of $22 \%$ of the light absorbed in the 400 to $700 \mathrm{~nm}$ region. Light use efficiency by plants depends not only on the photosynthetic efficiency of plants, but also on the efficiency of the interception of light (Wilson et al., 1992).

De Koning (1989) and Wilson et al. (1992) reported that, when light is limiting, a linear function exists between light reduction and decreased growth with a $1 \%$ increase in growth occurring with a $1 \%$ increase in light under light levels up to $200 \mathrm{~W} / \mathrm{m}^{2}$. The optimum leaf area index varies with amount of sunlight reaching the crop. Under full sun, the optimum LAl is 7 at full at $60 \%$ of full sun the optimum is 5 , at $23 \%$ full sunlight, the optimum is only 1.5 (Salisbury and Ross 1978). Mature canopies of greenhouse sweet pepper have a relatively high leaf area index of approximately 6.3 when compared with the greenhouse cucumbers (3.4) and tomatoes (2.3) (Hand et al 1993 and De swart 2007). 
Abd-El Baky, H.M. et al.

Many crops in greenhouses are successfully propagated using only net solar radiation as the predictor of transpiration (calorie counter) (Jones, 1998). Potential Evapotranspiration was calculate from the micrometeorological data using the FAO Penman-Monteith equation (FAO, 1992) values were corrected using a crop coefficient (Doorenbos and Kassam 1979) to give the crop Evapotranspiration ( $\left.E T_{c}\right)$.

There is a wider range in the production (quantity and quality) due to deep effect of the environmental factors besides the management factors.

The objective of this work is to study the effect of environmental factors on sweet pepper production and irrigation management under different greenhouse forms.

\section{MATERIALS AND METHODS}

\section{Site and greenhouse forms (specifications)}

The experiments were carried out during agriculture season of 2002/2003, in three different greenhouse forms, N-S oriented, located at Ismalia City (latitude $32.26{ }^{\circ} \mathrm{N}$, longitude $30.33^{\circ} \mathrm{E}$, and altitude $10 \mathrm{~m}$ above the sea level) on the coastal area of eastern Egypt. Three different forms of greenhouse were used during the experimental work; gable-even-span form (fully controlled), flat roof net-house (screen house), and modified Quonset greenhouse, as shown in Fig. (1).

The geometric characteristics of the gable-even-span multi-greenhouse (fully controlled) are as follows: eaves height $5.28 \mathrm{~m}$, gable height $1.68 \mathrm{~m}$, span angle $25^{\circ}$, width $198 \mathrm{~m}$, length $80 \mathrm{~m}$, floor surface area $15,048 \mathrm{~m}^{2}$ and volume $66,813.12 \mathrm{~m}^{3}$ as revealed in Fig. (1a). It is covered with single

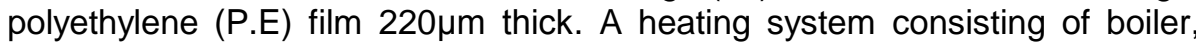
condenser, heat distributing system, and thermal pump was used to warm up the ambient air inside the greenhouse. Thermal screen was also used and closed during the nighttime to reduce the heat loss when the outside air temperature is low. The thermal screen is operated based on rules used in common practice, (shade value 50\% and energy saving 20\%). Cooling by ventilation was utilized by opening windows during daylight when the outside air temperature was lower than $20^{\circ} \mathrm{C}$. However, when the ambient air temperature outside the greenhouse was higher than $20^{\circ} \mathrm{C}$, the evaporative cooling system (fan-pad system) was operated. Drip irrigation system with adequate hydrostatic pressure for maximum use rate of water was functioned for watering sweet pepper plants during these experiments. The drippers (long-bath GR 2 liter/hr discharge) were uniformly alternative distributed with $37.5 \mathrm{~cm}$ dripper spacing throughout each row of plants inside the greenhouses. Fertilization unit is use for application of nutrient elements with irrigation by simultaneous injection of five number of fertilizer. A permanent on line control of electrical conductivity $(\mathrm{EC})$ and $(\mathrm{pH})$ control is maintained during irrigation and fertilization execution by automatic adjustment of fertilizers injection rate.

The geometric characteristics of the flat roof net-house are as follows: width $124 \mathrm{~m}$, length $172 \mathrm{~m}$, height $3.4 \mathrm{~m}$, floor surface area $21,328 \mathrm{~m}^{2}$, and volume $72,515.2 \mathrm{~m}^{3}$ as shown in Fig. (1b). White fine-mesh screen (Bio-net 
50-mesh round monofilament threads of $0.24 \mathrm{~mm}$ diameter, 50 threads per inch) was used to cover the net-house. The effective transmission of screen is ranged between 45 to $50 \%$. The long side $(172 \mathrm{~m})$ of this house is oriented with E-W direction with 15 spans (each span is $8 \mathrm{~m}$ ). Moveable black shade $40 \%$ was spread under the roof to reduce the solar radiation during the daylight, while crop tensile wire reached $2.9 \mathrm{~m}$ from the soil level. Injection fertilizer pump was used for adding nutrient elements with irrigation water. Three injection fertilizers pumps with 5 inlets are used and adjusted by pressure valve.

The geometric characteristics of the modified Quonset greenhouse are as follows: width $9.2 \mathrm{~m}$, length $39.0 \mathrm{~m}$, eaves height $3.2 \mathrm{~m}$, vertical wall height $2.0 \mathrm{~m}$, arc height $1.2 \mathrm{~m}$, floor surface area $358.8 \mathrm{~m}^{2}$, and volume $1004.64 \mathrm{~m}^{3}$ as shown in Fig. (1c). It is N-S oriented and covered with single

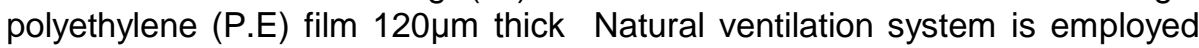
during the experiments by opening the upper middle plastic cover using a manual winch. Drip irrigation system with adequate hydrostatic pressure for maximum use rate of water was also used for watering sweet pepper plants during these experiments.

\section{General plant culture}

Plants were grown in light sandy soil and transplanted in August. Fresh fruits harvesting started from November to July with the total crop periods ranged between 272 to 334 days for the three different forms of greenhouses. Green/red sweet peppers (Capsicum annuum L. C.v. "Lorca", De Ruiter.Co) was used. Sweet peppers were planted on pile of $1.6 \mathrm{~m}$ wide, $0.50 \mathrm{~m}$ between alternative piles, $37.5 \mathrm{~cm}$ between plants in each single row and $1.10 \mathrm{~m}$ service aisle. The intensity of sweet pepper plants was $3.3 \mathrm{plants} / \mathrm{m}^{2}$. Pepper plants are managed to Dutch system (V. system) with a two main stems per plant, resulting in a density of $6.6 \mathrm{stems} / \mathrm{m}^{2}$ of floor surface area from an initial planting density of 3.3 plants $/ \mathrm{m}^{2}$.

Water was supplied through the drip irrigation system and scheduled by solar energy ( 2 liter $/ \mathrm{m}^{2} / 500$ Joule accumulated) daily applied between 3 to $7.5 \mathrm{~mm} /$ day (2 to 4 times daily) after transplanting. Plants were irrigated with complete nutrient elements with concentration levels developed for different systems. Nutrient levels for different sweet pepper plants and growth stages were adapted as follows: from transplanting to flowering stage NPK concentration in the irrigation was $100-100-100$ ppm followed by $100-40-100$ until fruit set on the third order flowering and 120-45-120 ppm until the end of the experiment.

\section{Environmental set-points}

Air temperature set-points were $21-30^{\circ} \mathrm{C}$ during daylight and $16-18^{\circ} \mathrm{C}$ at nighttime. Air relative humidity set-point ranged from $40-90 \%$. The recommended vapour pressure deficit (VPD) should be between $3-7 \mathrm{~g} / \mathrm{m}^{3}$ (Rylski and Spigelman, 1982 and 1986 ; Rylski, 1986 ; Portree, 1996 ; and De Swart 2007). The solar radiation in the range of $200-450 \mathrm{~W} / \mathrm{m}^{2}$ inside the gable-even-span greenhouse was measured and recorded for short and long terms, while for other greenhouses the microclimatic conditions were control 
using some equipment like black net sheet and natural ventilation system ( De Swart 2007 and Eviatar 2007).

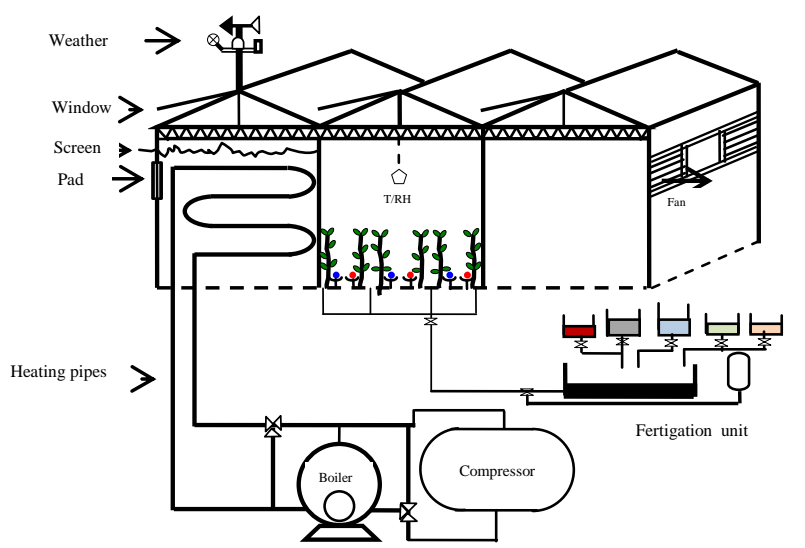

(a) Gable-even-span greenhouse (Multi-span)

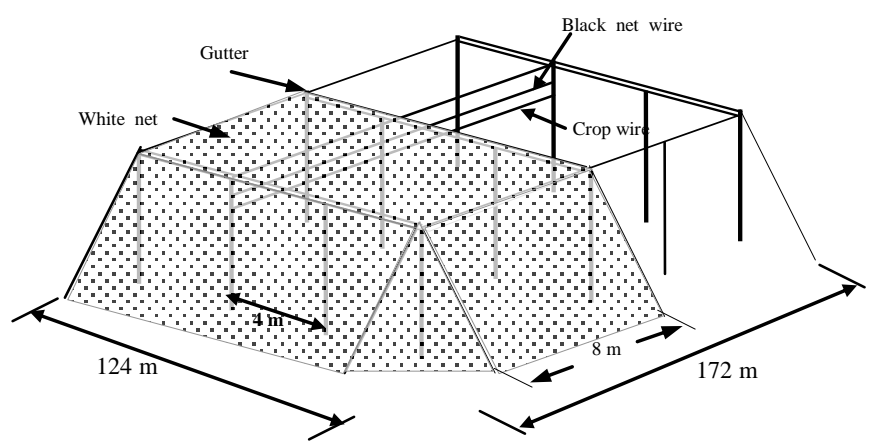

(b) Flat roof net-house

(c)

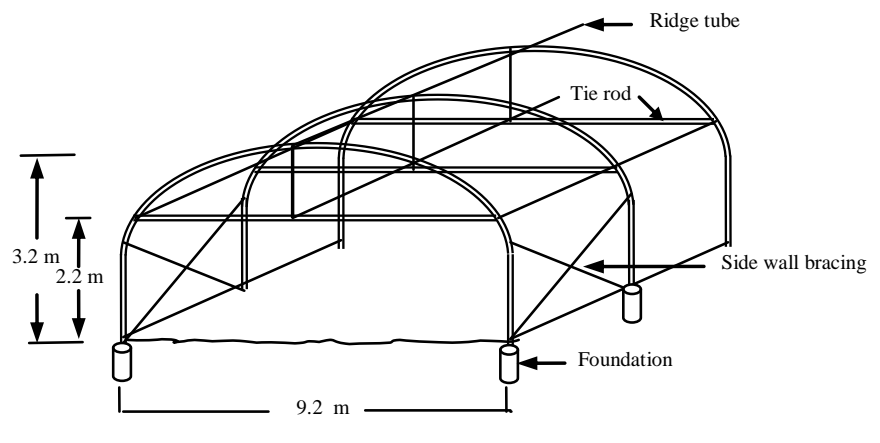

Modified Quonset greenhouse

Fig (1): Three different greenhouse forms; (a) gable-even-span greenhouse (fully controlled), (b) flat roof net-house, and (c) modified Quonset greenhouse. 


\section{Measurements and data acquisition unit Climatic measurements}

In order to measure and record the outside climatic conditions, meteorological station (PRIVA Computer, Inc., Vineland, Netherland) included the following sensors: light intensity, wind speed and direction, ambient air temperature, air relative humidity and rain was installed just above the greenhouses. The recorded data were stored in the memory for output to a printer or to a computer for storage on disk. The time interval for data recording was 1 hour with data acquisition every 30 seconds for integrated measurements. The calibration of all sensors and the logger was completed successfully at the beginning of the experimental work. The microclimatic conditions inside the gable-eve-span greenhouse (fully controlled) were measured using control board which was mounted on a height of which can weekly be adjusted according to the growth stage of crop. While the microclimatic conditions (air temperature and air relative humidity) inside the flat roof net-house and the modified Quonset greenhouses were also measured and recorded every hour using data-logger (Model PRO HOBO 032 - 08 Onset. Ltd. USA). The net solar radiation inside the nethouse and the modified Quonset greenhouse was measured using Quantum meter (Model QMSS-Sun apogee. Ltd., USA) Vapor pressure deficit (VPD) was computed using the following formulas (Prenger and Ling, 2004).

$$
\begin{aligned}
& V_{\text {sat }}=\exp (\mathrm{Z}) \\
& Z=A / T+B+C T+D T^{2}+E T^{3}+F \ln T \\
& V P_{\text {air }}=\left(V P_{\text {sat }} X R H\right) \div 100 \\
& V P D=V P_{\text {sat }}-V P_{\text {air }}
\end{aligned}
$$

Where:

$$
\begin{array}{ll}
\mathrm{A} & =-1.0440397 \times 10^{4} \\
\mathrm{~B} & =-1.1294650 \times 10^{1} \\
\mathrm{C} & =-2.7022355 \times 10^{-2} \\
\mathrm{D} & =+1.2890360 \times 10^{-5} \\
\mathrm{E} & =-2.4780681 \times 10^{-9} \\
\mathrm{~F} & =+6.5459673 \\
\mathrm{~T} & =\text { air temperature in }{ }^{\circ} \mathrm{R} \\
\mathrm{RH} & =\text { air relative humidity (\%) of the greenhouse. } \\
\mathrm{VP}_{\text {sat }} & =\text { air saturation vapor pressure (psi). } \\
\mathrm{VP}_{\text {air }} & =\text { vapor pressure of the air (psi). }
\end{array}
$$

\section{Growth measurements}

Plant samples were taken periodically throughout the growth cycles to measure vegetative, flowering and yields. The morphological traits are; plant height, internodes length, number of leaves and leaf area. The flowering traits are; number of flowers per plant and fruit setting percentage. Once every two weeks the fresh fruits were harvested and graded according to standard sizing in Europe and USA (Elio, 2004). Total marketable fruit $/ \mathrm{m}^{2}$ and average fruit weight were recorded. With regard to fruit quality shape index and fruit export percentage were also determined. Some chemical analysis such as; vitamin C content was determined. Electric balance, metric scale, electronic 
digital caliper, micrometer, labels and digital planimeter Model (KP-90 SOKKIA Ltd., Japan) were used for these measurements.

Irrigation performance indicators

Irrigation performance indicators were analyzed for the three different greenhouse forms during sweet pepper growth period. The three irrigation performance indicators (Annual Relative Irrigation Supply (ARIS), Irrigation Water Use Efficiency (IWUE), and Annual Irrigation Water Productivity (AWP)) according to Fernandez et al. (2007) were determined as follows:-

Annual relative irrigation supply (ARIS):

ARIS is defined as the ratio of annual irrigation water supply (AIWS) and the total irrigation water requirements (AWR).

\section{ARIS = AIWS $/$ AWR $\quad, \%$}

\section{Annual irrigation water productivity (AWP):}

AWP is defined as the annual value of crop production (L.E) to annual irrigation water supply $\left(\mathrm{m}^{3}\right)$.

AWP = Annual value of crop production $/$ AIWS , L.E $/ \mathrm{m}^{3}$ Irrigation water use efficiency (IWUE):

WUE is defined as the ratio of the marketable pepper yield to the total crop irrigation water supply (AIWS).

IWUE $=$ Crop production $\left(\mathrm{kg} / \mathrm{m}^{2}\right) / \operatorname{AIWS}(\mathrm{m}) \quad, \mathrm{kg} / \mathrm{m}^{3}$

For the rest of this research work the gable-even-span greenhouse (fully controlled), flat roof net-house, and modified Quonset greenhouse are referred to as G!, G2, and G3, respectively.

\section{RESULTS AND DISCUSSIONS}

The primary objective of a greenhouse is to produce higher fresh yield outside the cultivation season, which is possible by maintaining the optimum microclimate at every stage of the crop growth.

1- Effect of Greenhouse Structural forms on Microclimatic conditions:-

Microclimatic conditions of the three different forms of greenhouses are mainly affected by many variables. Some are related to the structural frame of greenhouse and its orientation, and the others are related to the climatic circumstances namely, intensity of solar radiation during daylight, outside air temperatures throughout the day, air relative humidity, and wind speed.

\section{1- Air Temperature}

The effectiveness of greenhouse structural forms in energy conservation was investigated in particular for the coldest days during the experimental period. The air temperatures inside the three greenhouses (G1, G2, and G3) were compared with the outside air temperature as an important measure of the effectiveness of the structural forms. The maximum, minimum, daylight average, and nightly average of the air temperatures recorded outside and inside the three different structural forms of greenhouses are summarized and listed in Table (1). 
J. of Soil Sciences and Agricultural Engineering, Vol. 1 (3), March, 2010 1 
Abd-El Baky, H.M. et al.

The air temperature inside the three greenhouses (G1, G2, and G3) during daylight time varied between $22.1^{\circ} \mathrm{C}$ and $25.3^{\circ} \mathrm{C}, 13.7^{\circ} \mathrm{C}$ and $31.2^{\circ} \mathrm{C}$, and between $13.7^{\circ} \mathrm{C}$ and $36.5^{\circ} \mathrm{C}$, respectively, whereas, the outside air temperature ranged from $13.1^{\circ} \mathrm{C}$ to $29.5^{\circ} \mathrm{C}$. At nighttime, the air temperature inside the three greenhouses $\left(\mathrm{G} 1, \mathrm{G} 2\right.$, and $\mathrm{G} 3$ ) varied between $17.1^{\circ} \mathrm{C}$ and $18.2^{\circ} \mathrm{C}, 11.8^{\circ} \mathrm{C}$ and $25.1^{\circ} \mathrm{C}$, and between $9.0^{\circ} \mathrm{C}$ and $30.4^{\circ} \mathrm{C}$, respectively, whereas, the outside air temperature ranged from $9.7^{\circ} \mathrm{C}$ to $24.5^{\circ} \mathrm{C}$. The highest air temperatures recorded inside the three greenhouses at nighttime $\left(22.4^{\circ} \mathrm{C}, 31.2^{\circ} \mathrm{C}\right.$, and $36.5^{\circ} \mathrm{C}$, respectively) during August month. While, the lowest air temperatures recorded inside the greenhouse at nighttime $\left(17.1^{\circ} \mathrm{C}\right.$, $11.8^{\circ} \mathrm{C}$, and $9.0^{\circ} \mathrm{C}$, respectively) during January month. The fluctuations of air temperature surrounding the crops play an important role for their growth rate, development, and productivity. Fluctuation changes in air temperature, caused by the ON-OFF control board, were evidently observed inside the first greenhouse (fully controlled).

A temperature gradient developed along the centerline of each greenhouse and its value varied with time during each heating cycle.

The hourly average air temperatures inside, outside, and set-points for the three different forms of greenhouses during the different seasons of growth period of sweet pepper are plotted Fig. (2). For the duration of the summer months the air temperatures during daylight and at nighttime inside the fully controlled greenhouse were closest to the set-point temperature due to the ON-OFF control board as shown in Fig. (2, A). Whereas, the air temperatures inside the other structural forms (G2 and G3) were closest to the outside air temperature. Consequently, the air temperatures inside these forms of structure were at unsuitable level. During the autumn season the air temperatures inside G2 and G3 were at the desired levels for vegetative and generative cycles as revealed in Fig.(2, B). During winter season the daily average air temperatures inside the three different structural forms (G1, G2, and $\mathrm{G} 3$ ), respectively, were $23.3^{\circ} \mathrm{C}, 17.9^{\circ} \mathrm{C}$, and $18.2^{\circ} \mathrm{C}$. The air temperatures inside the net-house and modified Quonset forms were lower than that of the set-point temperature as indicated in Fig. (2, C). During spring season the daily average air temperatures inside the three different structural forms (G1, G2, and G3), respectively, were $24.3^{\circ} \mathrm{C}, 20.3^{\circ} \mathrm{C}$, and $21.4^{\circ} \mathrm{C}$. Fig. (2), also evidently revealed that the nightly average air temperature inside the fully controlled greenhouse throughout the experimental period was at and around the set-point temperature due to the heating effect of the heating system. Whereas, the nightly average air temperatures inside the other two greenhouses throughout the experimental period were lower than that the desired level of temperature. The obtained data revealed that, the nightly average air temperature differences between the inside and outside of the three different structural forms varied from month to another and during the experimental period according to the total heat lost. The fully controlled greenhouse provided a heating effect of $5.0^{\circ} \mathrm{C}$ during winter season due to operate the heating system. While, the flat-roof net-house provided a heating effect of $1.2^{\circ}$ due to heat energy stored in the floor surface area. The nightly average air temperature inside the modified Quonset greenhouse during 
winter season was lower than that outside by $0.3^{\circ} \mathrm{C}$, due to the sensible and latent heat energy losses.

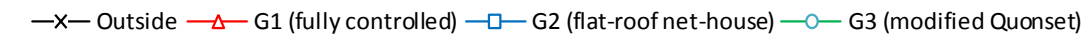
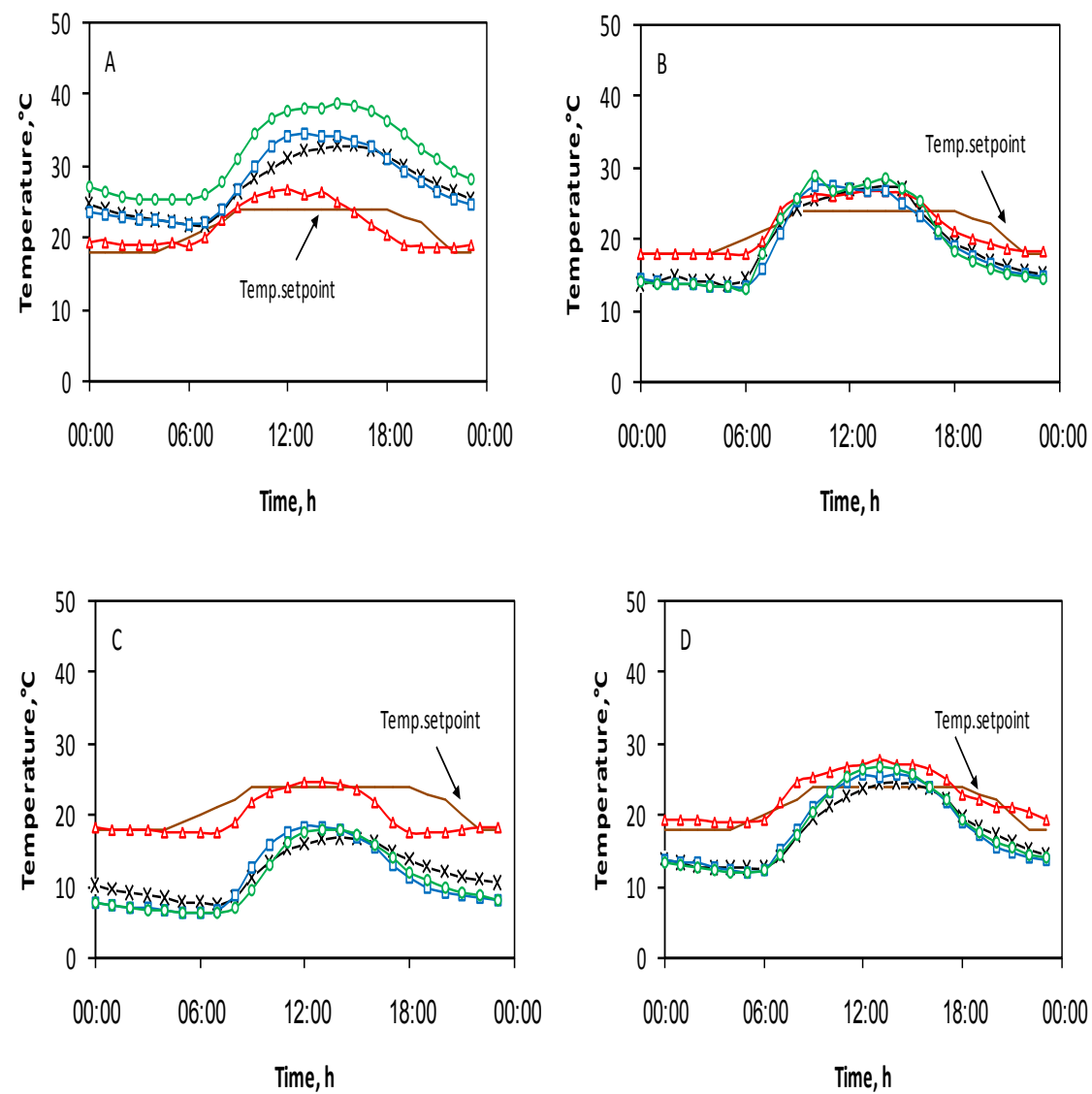

Fig. (2): Cyclic changes in air temperature within the three greenhouses (G1, G2, and G3) during Summer (A); Autumn (B); Winter(C) and spring (D) for the sweet colour pepper.

\subsection{Air relative humidity.}

The variation of air relative humidity as a function of time within the three different structural forms of greenhouses during the experimental period is plotted in Fig. (3). The air relative humidity inside the three different forms of greenhouses, respectively, ranged from 64.1 to $93.0 \%, 43.0$ to $90.9 \%$, and from 37.5 to $95.8 \%$, whereas the outside air relative humidity was in the range of 30.7 to $71.3 \%$. The nightly average air relative humidity within the three greenouses (G1, G2, and G3) during the experimental period, 
respectively, was $89.7 \%, 84.8 \%$, and $90.0 \%$. While, the nightly average outside air relative humidity was $66.9 \%$. Cyclic changes were also observed in the air relative humidity, and the humidity ratio which computed from wetbulb depression. During summer months, the daily average air relative humidity outside and inside the three greenhouses were $65.5 \%, 66.0 \%$, $84.0 \%$, and $71.1 \%$, respectively, as shown in Fig. (3, A). The daily average air relative humidity outside and inside the three greenhouses (G1, G2, and G3) during autumn months, respectively, were $87.6 \%, 59.4 \%, 86.8 \%$, and $75.4 \%$ as revealed in Fig. (3,B). During winter months, the daily average air relative humidity outside and inside the three greenhouses were $90.7 \%$, $65.0 \%, 88.2 \%$, and $81.0 \%$, respectively, as shown in Fig. $(3, C)$. Whereas, the daily average air relative humidity outside and inside the three greenhouses (G1, G2, and G3) during spring months, respectively, were $78.3 \%, 63.0 \%$, $85.3 \%$, and $65.3 \%$ as revealed in Fig. $(3, \mathrm{D})$. Most protected cropping grow best within a fairly restricted range, typically $60 \%$ to $85 \%$ air relative humidity at nighttime for many varieties (Öztürk and Bascetincelik, 2003). High air relative humidity is the main response of pathogenic organisms. Most pathogenic spores can not germinate at air relative humidity below $85 \%$. Low air relative humidity increases the evaporation demand on the plant to the extent that moisture stress can occur, even when there is an ample supply of water to the roots. Normal plant growth inside the greenhouse generally occurs at air relative humidity ranged from 30 to $80 \%$ (Hanan, 1998).

\subsubsection{Vapor pressure deficit}

Vapor pressure deficit (VPD) is a valuable way to measure greenhouse climate. It can be used to evaluate the disease threat, condensation potential, and irrigation needs of a greenhouse crops. Vapor pressure deficit is the difference between the amount of moisture in the air and how much moisture the air can hold when it is saturated. Higher vapor pressure deficit increases the transpiration demand, influencing how much moisture from plant tissues is transferred into the greenhouse air Consequently, VPD is being used to predict crop water needs in some commercial irrigation systems. Several studies that explore disease pathogen survival at different climate levels reveal two critical values of VPD. Studies showed that fungal pathogens survive best below $0.43 \mathrm{kPa}$ (Prenger and Ling, 2004). Furthermore, disease infection is most damaging below $0.20 \mathrm{kPa}$. Thus, the greenhouse climatic conditions should be kept above $0.20 \mathrm{kPa}$, to prevent disease and damage to crops. The variation of vapor pressure deficit as a function of time within the three different structural forms of greenhouses during the experimental period is plotted in Fig. (4). For the duration of the experimental period, the daily averages vapor pressure deficit inside the three different structural forms of greenhouses (G1, G2, and G3), respectively, were $0.55,1.11$, and $1.06 \mathrm{kPa}$. Whereas, the nightly averages vapor pressure deficit inside the three different greenhouses (G1, G2, and G3) were $0.55,1.11$, and $1.06 \mathrm{kPa}$, respectively. 
$-\mathrm{X}-$ Outside $\longrightarrow-\mathrm{G} 1$ (fully controlled) $-\square-\mathrm{G} 2$ (flat-roof net-house) $-0-\mathrm{G} 3$ (modified Quonset)
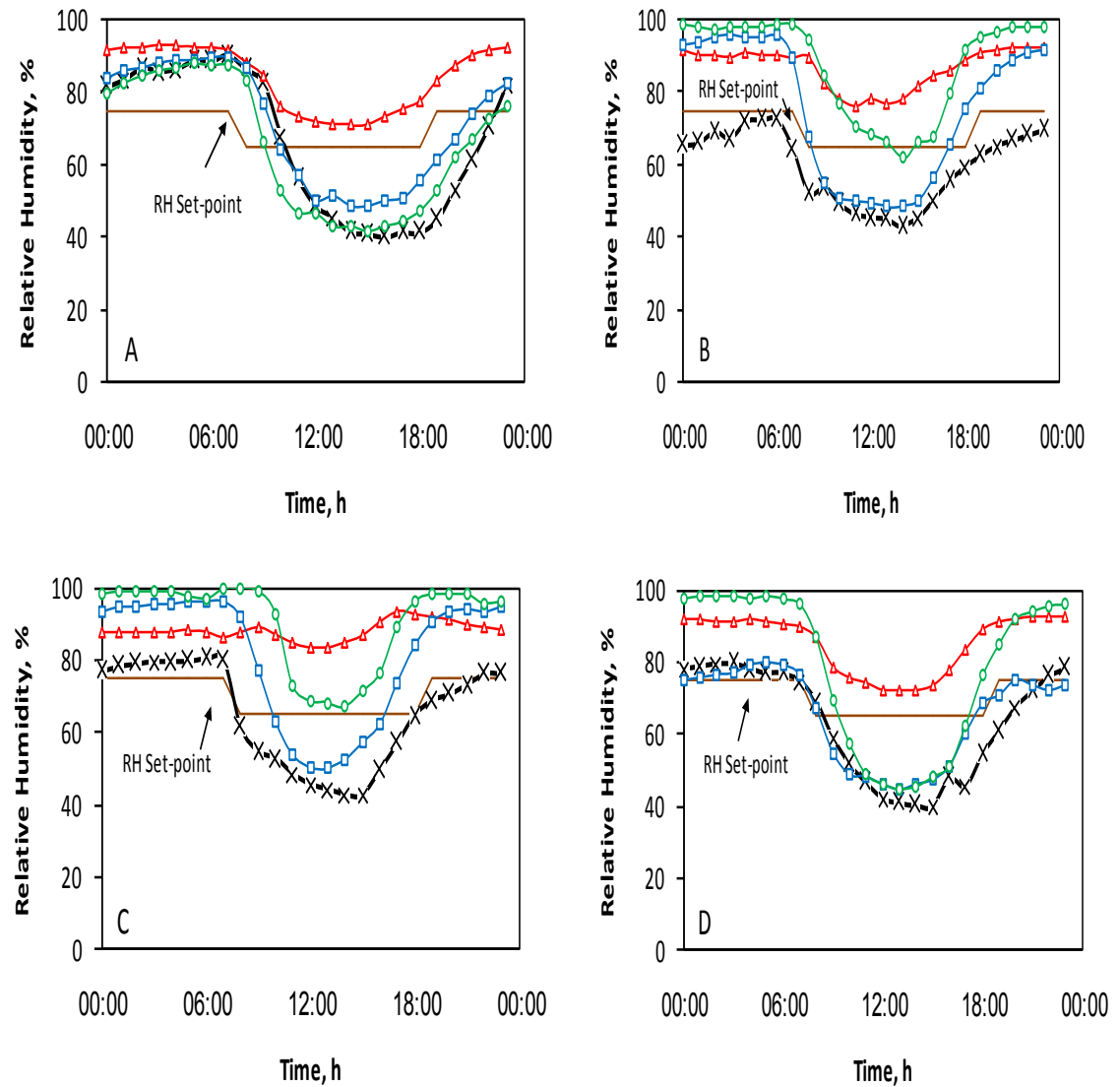

Fig. (3): Changes in air relative humidity within the three greenhouses (G1, G2, and G3) as a function of time during summer (A), autumn (B),; winter(C), and spring (D).

During summer months, the daily and nightly averages vapor pressure deficit (VPD) of the climatic conditions inside the fully controlled greenhouse (G1) were $0.61 \mathrm{kPa}(<1.0 \mathrm{kPa})$ and $0.26 \mathrm{kPa}(>0.20 \mathrm{kPa})$, respectively. Consequently, the VPD during daylight and at night times were at and around the recommended level $(1.0 \mathrm{kPa}<\mathrm{VPD}>0.20 \mathrm{kPa})$ as shown in Fig. $(4, \mathrm{~A})$. While, the daily and nightly averages vapor pressure deficit (VPD) of the climatic conditions inside the flat-roof net-house (G2) were $1.72 \mathrm{kPa}$ and 0.57 $\mathrm{kPa}$, respectively. Consequently, the VPD during daylight was greater than that the recommended level at that time, and at nighttime, it was at and around the recommended level (VPD $>0.20 \mathrm{kPa}$ ). Meanwhile, the daily and nightly averages vapor pressure deficit (VPD) of the climatic conditions inside 
the modified Quonset greenhouse (G3), respectively, were $2.32 \mathrm{kPa}$ and 1.00 $\mathrm{kPa}$, consequently, the VPD during daylight was greater than that the recommended level at that time, and at nighttime, it was almost at and around the recommended level (VPD $>0.20 \mathrm{kPa}$ ).

During autumn months, the daily and nightly averages vapor pressure deficit (VPD) inside the fully controlled greenhouse (G1) were $0.57 \mathrm{kPa}(<1.0$ $\mathrm{kPa})$ and $0.20 \mathrm{kPa}(=0.20 \mathrm{kPa})$, respectively. Consequently, the VPD during daylight was at and around the recommended level, but at nighttime it was in the damaging level as shown in Fig. (4, B). While, the daily and nightly averages vapor pressure deficit (VPD) of the climatic conditions inside the flat-roof net-house (G2) were $1.29 \mathrm{kPa}$ and $0.32 \mathrm{kPa}$, respectively. Consequently, the VPD during daylight was greater than that the recommended level at that time, and at nighttime, it was at and around the recommended level (VPD $>0.20 \mathrm{kPa}$ ). Meanwhile, the daily and nightly averages vapor pressure deficit (VPD) of the climatic conditions inside the modified Quonset greenhouse (G3), respectively, were $0.84 \mathrm{kPa}$ and 0.09 $\mathrm{kPa}$, consequently, the VPD during daylight was at and around the recommended level at that time, and at nighttime, it was in the damaging level as shown in Fig. (4, B). Thus, fungal diseases infection occurred in this greenhouse during that time.

During winter months, the daily and nightly averages vapor pressure deficit (VPD) inside the fully controlled greenhouse (G1) were $0.43 \mathrm{kPa}(<1.0$ $\mathrm{kPa})$ and $0.20 \mathrm{kPa}(=0.20 \mathrm{kPa})$, respectively. Consequently, the VPD during daylight was almost at and around the recommended level, but at nighttime it was in the damaging level as shown in Fig. $(4, C)$. While, the daily and nightly averages vapor pressure deficit (VPD) of the climatic conditions inside the flat-roof net-house (G2) were $0.59 \mathrm{kPa}$ and $0.15 \mathrm{kPa}(<0.20 \mathrm{kPa})$, respectively. Consequently, the VPD during daylight was almost at and around the recommended level at that time, but at nighttime, it was in the damaging level as shown in Fig. (4, C). Thus, fungal diseases infection occurred in this greenhouse during that time. Meanwhile, the daily and nightly averages vapor pressure deficit (VPD) of the climatic conditions inside the modified Quonset greenhouse (G3), respectively, were $0.43 \mathrm{kPa}$ and 0.07 $\mathrm{kPa}$, consequently, the VPD during daylight was almost at and around the recommended level at that time, but at nighttime, it was in the damaging level as shown in Fig. (4, C). Thus, fungal diseases infection also occurred in this greenhouse during that time.

During spring month, the daily and nightly averages vapor pressure deficit (VPD) inside the fully controlled greenhouse (G1) were $0.80 \mathrm{kPa}(<1.0$ $\mathrm{kPa})$ and $0.21 \mathrm{kPa}(>0.20 \mathrm{kPa})$, respectively. Consequently, the VPD during daylight was at and around the recommended level, but at nighttime it was in the damaging level as shown in Fig. (4, D). While, the daily and nightly averages vapor pressure deficit (VPD) of the climatic conditions inside the flat-roof net-house (G2) were $1.10 \mathrm{kPa}$ and $0.37 \mathrm{kPa}$, respectively. Consequently, the VPD during daylight was greater than that the recommended level at that time, and at nighttime, it was at and around the recommended level (VPD $>0.20 \mathrm{kPa}$ ). Meanwhile, the daily and nightly averages vapor pressure deficit (VPD) of the climatic conditions inside the 
modified Quonset greenhouse (G3), respectively, were $0.85 \mathrm{kPa}$ and 0.04 $\mathrm{kPa}$, consequently, the VPD during daylight was at and around the recommended level at that time, but at nighttime, it was in the damaging level as shown in Fig. (4, D). Thus, fungal diseases infection occurred in this greenhouse during that time.

$-\mathrm{X}-$ Outside $\longrightarrow-\mathrm{G} 1$ (fully controlled) $\longrightarrow \square-\mathrm{G} 2$ (flat-roof net-house) $\longrightarrow \mathrm{O}-\mathrm{G} 3$ (modified Quonset)
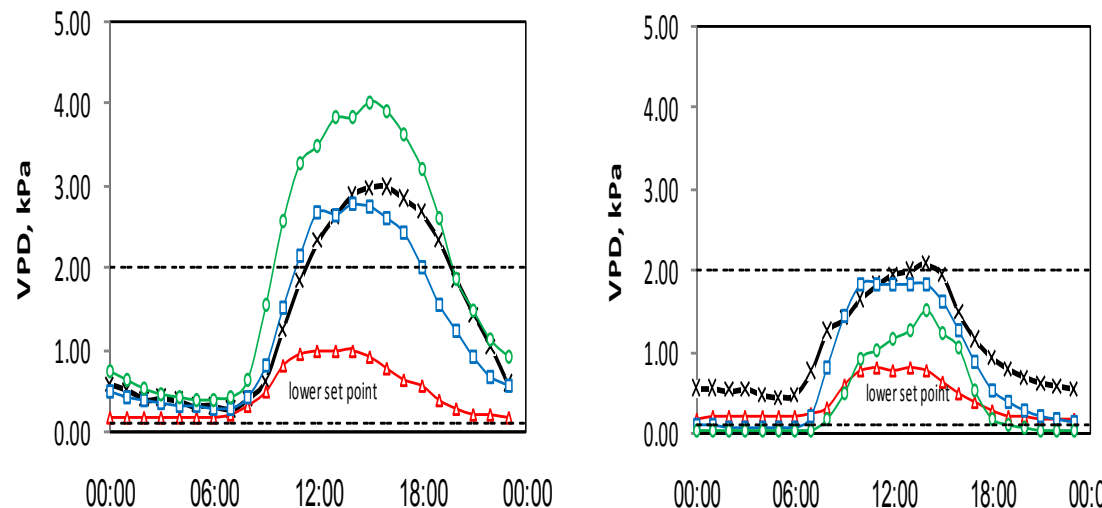

Time, $h$

Time, $h$
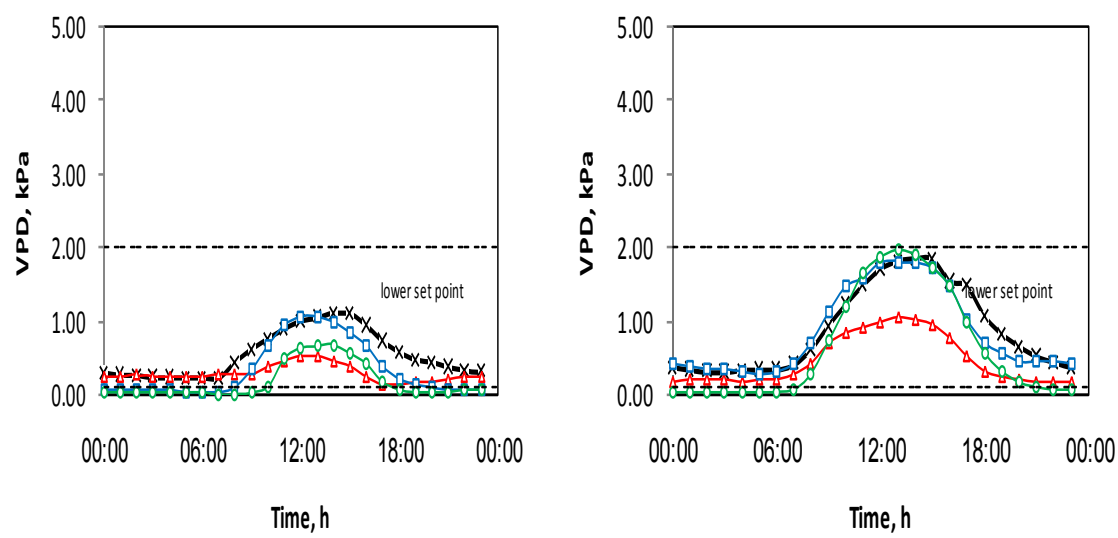

Fig. (4): Changes in vapor pressure deficit within the three greenhouses (G1, G2, and G3) as a function of time during summer (A), autumn (B),; winter(C), and spring (D).

\subsection{Solar Radiation}

For the duration of the experimental period, the hourly average total solar radiation flux incident on the horizontal surface outside and inside the greenhouses is plotted in Fig. (5). It evidently revealed that, the solar 
radiation flux incident either outside or inside the greenhouses increased gradually with solar time from sunrise until it reached the maximum value at or around noon. It then decreased gradually till it approached the minimum value at sunset. They varied from day to another and during the month according to the sky cover (clouds), solar altitude angle, and solar incident angle. The daily averages solar radiation flux incident outside and inside the three different structural forms of greenhouses (G1, G2, and G3), respectively, were $364.5,246.2,278.6$, and $306.9 \mathrm{~W} / \mathrm{m}^{2}$. The solar radiation flux incident inside the greenhouses was less than that outside, owing to, the reflectance, absorptivity, and transmissivity of the different covering materials.

During summer months, the daily average solar radiation flux incident outside and inside the three different structural forms (G1, G2, and G3), respectively, were $515.9,334.7,387.4$ and $433.23 \mathrm{~W} / \mathrm{m}^{2}$ as revealed in Fig. $(5, A)$. The greatest value was recorded inside the modified Quonset greenhouse (G3) due to its structural form which permitted great amount of solar radiation to be transmitted through the polyethylene cover. This amount of solar radiation was unsuitable particularly for the first 35 days after transplanting. Whereas, the solar radiation flux incident inside the fully controlled greenhouse considered as the best level for the first stage of growth (De swart 2007 and Eviatar 2007).

\section{$-\mathrm{X}-$ Outside $\longrightarrow-\mathrm{G} 1$ (fully controlled) $\rightarrow \square-\mathrm{G} 2$ (flat-roof net-house) $-0-\mathrm{G} 3$ (modified Quonset)}
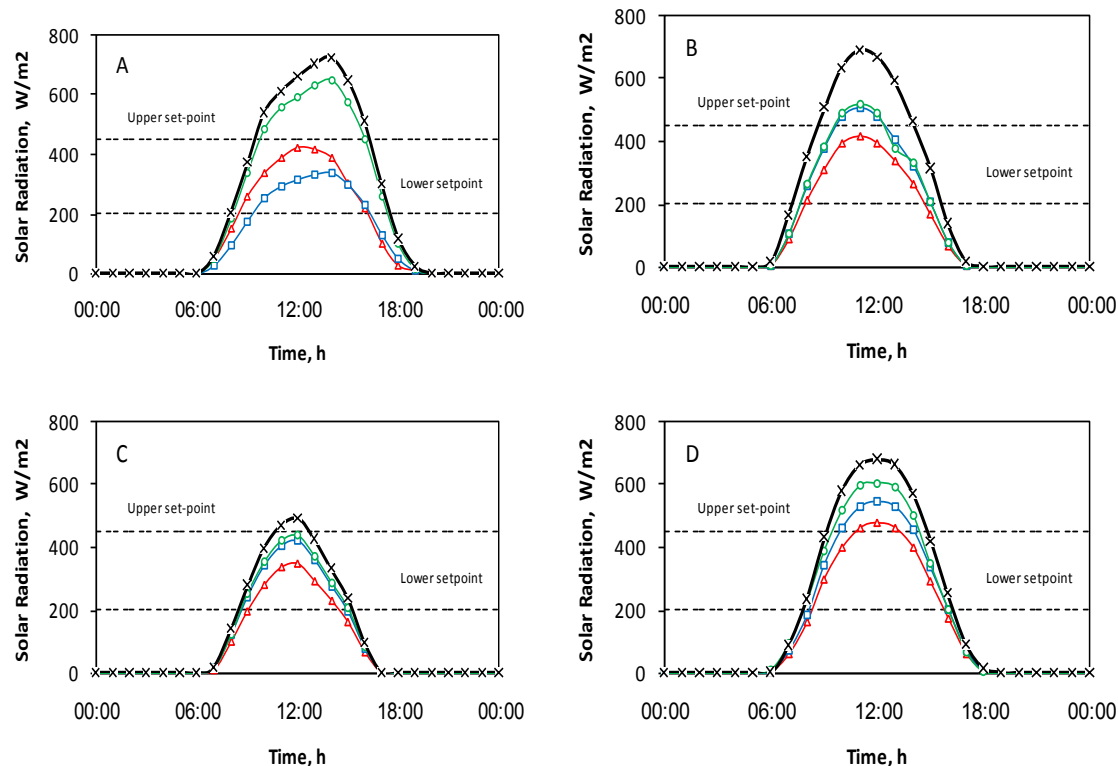

Fig (5): Hourly average total solar radiation flux incident outside and inside the three different structural forms (G1, G2, and G3) during summer (A); autumn (B); winter(C) and spring (D) season for the growth period of sweet pepper. 
To determine the solar radiation flux incident inside the three greenhouses as a function of solar radiation outside, the hourly average solar radiation flux incident on the horizontal level inside the greenhouses $\left(R_{i}\right)$ was plotted against solar radiation flux incident outside (Ro) (Fig. 6). Regression analysis revealed a highly significant linear relationship $(r(G 1)=0.976 ; r$ $(\mathrm{G} 2)=0.916 ; r(\mathrm{G} 3)=0.990 ; \mathrm{P} \leq 0.001)$ between theses parameters. The regression equations for the best fit were:-
$R_{\mathrm{i}}(\mathrm{G} 1)=0.6510\left(R_{\mathrm{o}}\right)$
$R_{\mathrm{i}}(\mathrm{G} 2)=0.7115\left(R_{0}\right)$
$R_{i}(G 2)=0.8405\left(R_{0}\right)$
$R^{2}=0.9528$
$R^{2}=0.8388$
$R^{2}=0.9805$
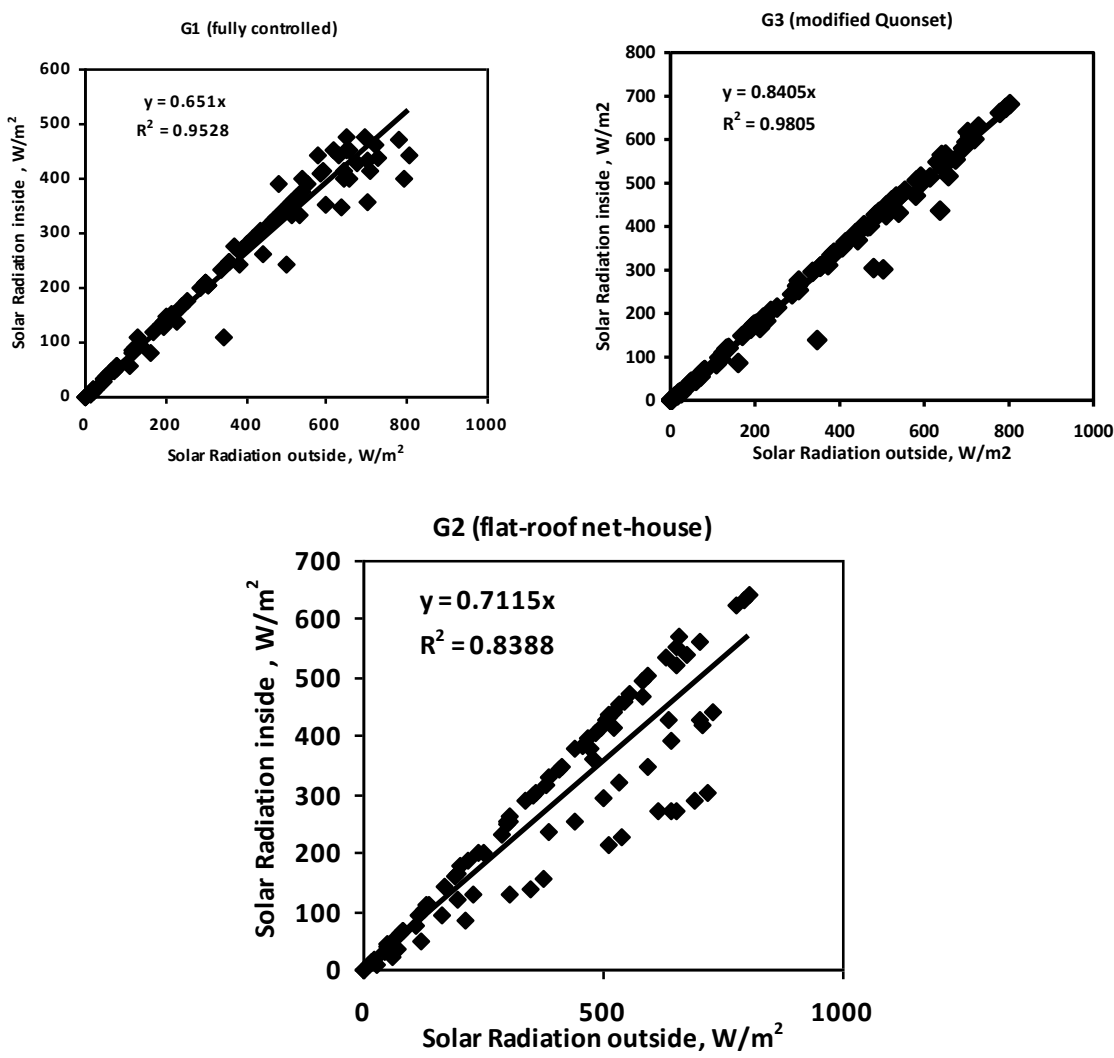

Fig (6): Solar radiation flux incident inside the three different structural forms of greenhouses (G1, G2, and G3) versus solar radiation flux incident outside.

\section{Effect of structural form of greenhouse on growth and productivity of} sweet pepper

The growth rate of sweet pepper inside the three different structural forms of greenhouse is listed in Table (2). The averages height of sweet pepper plant inside the three different structural forms of greenhouse (G1, 
G2, and G3), respectively, were $300.2,171.1$ and $191.8 \mathrm{~cm}$. Consequently the best growth rate was achieved inside the fully controlled greenhouse in terms plant height/season followed by G3 and G2. The weekly average plant height rate was $6.25,4.80$ and $4.65 \mathrm{~cm}$ for the three different greenhouses, respectively. The total leaf area index (LAl) reached to $6.12,2.20$ and 2.41 for the three different greenhouses (G1, G2, and G3), respectively. The highest value of leaf area index (LAI) was achieved during winter season for three greenhouses.

Table (2): Seasonal growth of sweet pepper inside the three different structural forms of greenhouse

\begin{tabular}{lccccccccc}
\hline \multirow{2}{*}{ Season } & \multicolumn{3}{c}{$\begin{array}{c}\text { Plant height } \\
\text { (cm)/season }\end{array}$} & \multicolumn{3}{c}{$\begin{array}{c}\text { Plant height rate } \\
\text { (cm/week) }\end{array}$} & \multicolumn{2}{c}{ leaf area index (LAI) } \\
\cline { 2 - 10 } & G1 & G2 & G3 & G1 & G2 & G3 & G1 & G2 & G3 \\
\hline Transplanting & 15.3 & 15.3 & 15.3 & 0.0 & 0.0 & 0.0 & 0.04 & 0.04 & 0.04 \\
Summer & 52.1 & 23.5 & 21.5 & 5.8 & 5.9 & 5.4 & 1.06 & 0.40 & 0.36 \\
Autumn & 92.9 & 92.3 & 83.4 & 7.7 & 7.7 & 6.9 & 1.73 & 1.23 & 1.16 \\
Winter & 80.7 & 25.3 & 56.6 & 5.8 & 1.8 & 4.0 & 1.71 & 0.34 & 0.62 \\
Spring & 74.5 & 30.0 & 29.3 & 5.7 & 2.3 & 2.3 & 1.62 & 0.23 & 0.27 \\
\hline Total & 300.2 & 171.1 & 190.8 & 25.0 & 19.1 & 18.6 & 6.12 & 2.20 & 2.41 \\
\hline Average & 75.1 & 42.8 & 47.7 & 6.25 & 4.80 & 4.65 & 1.53 & 0.55 & 0.60 \\
\hline
\end{tabular}

The total number of flowers, total fruits set on plant, and rate of fruit set for the three different structural forms of greenhouse are summarized and listed in Table (3). The greatest total number of flowers (78.0), total fruits set on plant (34.35), and rate of fruit set $(44.03 \%)$ were achieved inside the fully controlled greenhouse, due to all microclimatic conditions were provided and maintained at and around the desired level for sweet pepper crop. As the ambient air temperature surrounding the sweet pepper plants is increased over $35^{\circ} \mathrm{C}$, the percentage of flowerage, vitality of insemination seeds, and stem strength are reduced making the growth rate and fruit set at minimum levels. The biochemical reactions in all crops particularly sweet pepper crop are mainly controlled by enzymes that are heat sensitive. Numerous biochemical reactions involved in the photosynthesis and respiration processes. These all have the net effect on building carbohydrates and storing energy.

Table (3): Number of flowers, total fruits on plant, and fruit set of sweet pepper inside the three different greenhouses.

\begin{tabular}{cccc}
\hline Systems & No. of flowers per plant Total fruits per plantFruit set rate (\%) \\
\hline Greenhouse 1 & 78.00 & 34.35 & 44.03 \\
Greenhouse 2 & 60.00 & 13.56 & 22.61 \\
Greenhouse 3 & 56.00 & 12.10 & 21.61 \\
\hline
\end{tabular}

The average fruit length, fruit diameter, shape index, fruit weight, fresh yield percentage of grad 1, and content of vitamin $C$ are summarized and listed in Table (4). Due to the reasons discussed previously, the average fresh yield of sweet pepper per square meter of floor surface area for the 
three different structural forms of greenhouse, respectively, were 22.900, 8.272 , and $6.972 \mathrm{~kg} / \mathrm{m}^{2}$. Consequently, the fully controlled greenhouse increased the fresh yield of sweet pepper by $176.8 \%$ and $228.5 \%$ as compared with the greenhouse 2 and greenhouse 3, respectively. Also the fully controlled greenhouse gave the highest percentage of grade $1(85.66 \%)$ as compared with the flat-roof net-house (67.33\%) and modified Quonset greenhouse $(55.90 \%)$. Vitamin C contents of the fresh yield of sweet pepper which produced from the full controlled greenhouse, flat-roof net house, and modified Quonset greenhouse were 195.7, 177.0 and $153.3 \mathrm{mg} / 100 \mathrm{~g}$ of fresh weight, respectively.

Table (4): Total fresh yield and quality of sweet pepper from three different structural forms of greenhouse

\begin{tabular}{cccccccc}
\hline & \multicolumn{2}{c}{ Physical fruit_character } & \multicolumn{3}{c}{ Marketable yield } & \multicolumn{2}{c}{ Vitamin } \\
Systems & $\begin{array}{c}\text { Fruit } \\
\text { length } \\
\text { mm }\end{array}$ & $\begin{array}{c}\text { Fruit } \\
\text { diameter } \\
\text { mm }\end{array}$ & $\begin{array}{c}\text { Shape } \\
\text { index }\end{array}$ & $\begin{array}{c}\text { Fruit } \\
\text { weight (g) }\end{array}$ & $\begin{array}{c}\text { Total yield } \\
\text { kg/m }\end{array}$ & $\begin{array}{c}\text { Grad 1 } \\
\text { (\%) }\end{array}$ & $\begin{array}{c}\text { Content } \\
\text { mg/100 } \\
\text { g fruit }\end{array}$ \\
\hline G 1 & 95.00 & 85.00 & 1.12 & 200.00 & 22.900 & 85.66 & 195.7 \\
G 2 & 80.00 & 75.00 & 1.07 & 183.00 & 8.272 & 67.33 & 177.0 \\
G 3 & 80.00 & 75.00 & 1.07 & 173.00 & 6.972 & 55.90 & 153.3 \\
\hline
\end{tabular}

3.Irrigation performance indicators

Irrigation performance indicators (annual relative irrigation supply, irrigation water use efficiency, and annual water productivity) are listed and plotted in Table (5) and Fig.(7).

3.1. Annual relative irrigation supply (ARIS)

The total annual irrigation water supply (AIWS) for the three different structural forms of greenhouse was 2348,1878 , and $1750 \mathrm{~mm}$, respectively.

3.2. Irrigation water use efficiency (IWUE)

Irrigation water use efficiency (IWUE) for the three different structural forms of greenhouse was $9.75,4.40$ and $3.98 \mathrm{~kg} / \mathrm{m}^{3}$, respectively. The high value of irrigation water use efficiency (IWUE) which achieved inside the fully controlled greenhouse can be attributed to the high rate of crop production.

\subsection{Annual Water Productivity (AWP)}

Annual water production (AWP) is considered as an important indicator of irrigation performance. The annual water productivity (AWP) for the three different structural forms of greenhouse was $137.72,43.20$ and $33.79 \mathrm{~L} . \mathrm{E} / \mathrm{m}^{3}$, respectively. Consequently, the annual water productivity inside the fully controlled greenhouse $3-4$ times greater than that inside the greenhouse 2 and greenhouse 3 , respectively

Table (5): Irrigation performance indicators

\begin{tabular}{|c|c|c|c|c|c|c|c|}
\hline Systems & $\begin{array}{c}\text { Radiation } \\
\text { Sum } \mathbf{k J} / \mathrm{cm}^{2}\end{array}$ & $\begin{array}{l}\text { AWR } \\
(\mathrm{mm})\end{array}$ & $\begin{array}{l}\text { AIWS } \\
(\mathrm{mm})\end{array}$ & ARIS & $\begin{array}{c}\mathrm{CP} \\
\mathrm{kg} / \mathrm{m}^{2}\end{array}$ & $\begin{array}{l}\text { IWUE } \\
\mathrm{kg} / \mathrm{m}^{3}\end{array}$ & $\begin{array}{l}\text { AWP } \\
\text { L.E } / \mathrm{m}^{3}\end{array}$ \\
\hline Greenhouse 1 & 564.853 & 2259.41 & 2348 & 1.039 & 22.90 & 9.75 & 137.67 \\
\hline Greenhouse 2 & 468.878 & 1875.51 & 1878 & 1.001 & 8.276 & 4.40 & 43.20 \\
\hline Greenhouse 3 & 436.864 & 1747.46 & 1750 & 1.001 & 6.979 & 3.98 & 33.79 \\
\hline
\end{tabular}


Abd-El Baky, H.M. et al.

\section{Conclusions}

The main results of this experimental work could be summarized and listed as follows:-

(1) Protected cropping of vegetable crops in Egypt during summer months are favoured due to high air relative humidity, tremendous intensity of solar radiations, vapor pressure deficit, and air temperature fluctuation during that period.

(2) The average plant height inside the three different structural forms of greenhouse was $300.2,171.1$ and $191.8 \mathrm{~cm}$, respectively. Consequently, the fully controlled greenhouses increased the growth by $75.5 \%$, and $56.5 \%$ as compared with the other two greenhouses, respectively.

(3) The number of fruits which seated on the sweet pepper plants for the three different structural forms of greenhouse, respectively, was 34.35 , 13.56, and 12.10 fruit/plant

(4) The average leaf area index of sweet pepper plant during the experimental period for the three different structural forms of greenhouse was $6.12,2.20$, and 2.41 , respectively.

(5) The total fresh yield of sweet pepper crop per square meter of floor surface area for the three different structural forms of greenhouse, respectively, was $22.900,8.272$, and $6.972 \mathrm{~kg} / \mathrm{m}^{2}$.

(6) The contents of vitamin $C$ in the fresh yield of sweet pepper for the three different structural forms of greenhouse were 195.7, 177.0, and 153.3 $\mathrm{mg} / 100 \mathrm{~g}$ of fresh weight.

(7) The annual water productivity (AWP), for the three different structural forms of greenhouse was $137.67,43.20$, and $33.79 \mathrm{~L} . \mathrm{E} / \mathrm{m}^{3}$, respectively.

\section{REFERENCES}

Abdelbaky, H.M. (2006) "Sweet pepper as commercial crops". HEIA. J. of the Egyptian Hort. export industry. ISSUE No (32): $12-14$.

Bakker, J. C. (1989) "The effects of temperature on flowering, fruit set and fruit development of glasshouse sweet pepper (Capsicum annuum L.)". J. of Hort. Sci., 64(3):313 - 320.

Boonen, C. ; O. Joniaux ; K. Janssens ; D. Berckmans ; R. Lemeur ; A. Kharoubi ; and H. Pien. (2000) "Modeling dynamic behavior of leaf temperature at three-dimensional positions to step variations in air temperature and light" ASAE.Vol.43(6): 1755 - 1766.

Critten, D . L. ; and B. J. Bailey (2002) "A review of greenhouse engineering developments during the 1990s" Agricultural and Frost Meteorology 112: $1-22$.

Cropwat (1992) "A computer program for irrigation planning and management" FAO. Irrigation and drainage paper NO.46, Rome.Italy.

Dahesh, G. M. Y. (2007) "A thermal storage system for greenhouse heat energy conservation" Ph.D. Thesis, Faculty of Agriculture, Alexandria University. p 225. 
De Koning, A. N. (1996) "Quantifying the responses to temperature of different plant precesses involved in growth and development of glasshouse tomato" Acta Hort., 406: 99 - 104.

De Koning, A. N. (1989) "Development and growth of a commercially grown tomato crop" Acta Hort., 260: 267 - 270

De Swart, A. M. E. (2007) "Potential for breeding sweet pepper adapted to cooler growing conditions" Ph.D. Thesis, Wageningen Agicultrual University, Wageningen, The Netherlands. $152 \mathrm{p}$.

Dooren bos, J. ; and A. H. Kassam (1979) "Yield response to water" FAO. Irrigation and drainage paper NO.33, Rome. Italy.

Enoch, H .Z. ; and Y. Enoch. (1999). "The history and geography of the greenhouse. In: Stanhil, G., Enoch, H.Z. (Eds.), Greenhouse Ecosystems. Ecosystems of the World 20, Elsevier, Amsterdam, pp. 1-15.

Faostat, (2005) "Available from: <http://faostat.fao.org>, last update February 2005.

Fernandez, M .D. ; A. M. Gonzalez. ; J. Carreno ; C. Perez ; and S. Bonchela (2007) "Analysis of on-farm irrigation performance in Mediterranean greenhouses. Agric. Water Manage. 89: 251-260.

Georgios, K. S. (2001) "Temperature control and energy conservation in plastic greenhouse" J. agric. Engng Res.80(3): 251-259.

Graaf, A. ; and S. Reinhard (2006) "Cost-benefit analysis in interactive planning processes; an interactive instrument in an integrated approach." Wageningen Agricultural Economics Research Institute (LEI) The Netherlands, pp.1-13.

Hanan, J. J. (1998) "Greenhouse advanced technology for protected horticulture" Textbook, CRC Press, Bosa Raton, Boston, USA.

Jacques, A (2007) "Sweet pepper in Egypt: A challenge with opportunities. Enza seeds company presentation". www. Enza.com.

Jones, J. B. Jr .(1998) Plant nutritional manual. CRC Press, New York, USA.

Jovicich, E., D. J. Cantilffe and J. H. George (1999).Plant density and shoot pruning on fruit yield and quality of summer greenhouse sweet pepper crop in north central Florida", p. 184-190.

Jovicich, E., D. J. Cantilffe and P. J. Stoffella (2004). Fruit yield and quality of greenhouse- grown bell pepper as influenced by Density, Container and trellis system. Hortechnolgy. 14(4): 507-513.

Khah, E. M. and H. C. Passam. (1992). Flowering, fruit set and development of the fruit and seed of sweet pepper (Capsicum annuum L.) cultivated under conditions of high ambient temperature. J. of Hort. Sci. 67(2): 251- 25.

Kittas, C., N. Katsoulas A. Baille, J. A. Fernandez, P. F. Martinez and N. Castilla (2001).Transpiration and energy balance of a greenhouse rose crop in Mediterranean summer conditions. Acta Hort. 559: 395 - 400.

Ozturk, H. H. ; and A. Bascetincelik (2003) "Effect of thermal screen on the microclimate and overall heat loss coefficient in plastic tunnel greenhouses".J. Agric., 27:123-134. 
Portree, J. (1996) "Greenhouse vegetable production guide for commercial growers" Province of British Columbia Ministry of Agriculture, Fisheries and Food.

Prenger, J. J. ; and P. P. Ling (2004)"Greenhouse Condensation Control." understanding and using vapor pressure deficit (VPD). Fact Sheet (Series) $A E X-800$. Ohio state University Extension, Columbus, USA.

Pressman, E., H. Moshkovitch, K. Rosenfeld, R. Shaked, B. Gamliel and B. Aloni (1998). Influence of low night temperatures on sweet pepper flower quality and the effect of repeated pollinations, with viable pollen, on fruit setting. J. of Hort. Sci. \& Biotechnology 73(1):131-136.

Rylski, I. (1986) . Pepper (Capsicum). P. 341-352.In Shaul P. Monselise (ed) CRC Handbook of fruit set of sweet pepper and development. CRC press, Inc. Boca Raton, Florida.

Rylski, I., and M. Spigelman (1982).Effect of different diurnal temperature combinations on fruit set of sweet pepper. Sci. Hortic 17: 101-106.

Rylski, I., and M. Spigelman (1986). Effect of shading on plant development, yield and fruit quality of sweet pepper grown under conditions of high temperature and radiation. Sci. Hortic 29: 31-45.

Salisbury, F. B. and C. W. Ross (1978). Plant Physiology 2nd edition. Wadsworth Publishing Company, Inc. Belmont California.

Van Ooteghem, R. J. C. (2007). Optimal control desige for a solar greenhouse. PhD. Thesis, Wageningen Agicultrual University, Wageningen, The Netherlands. $304 \mathrm{p}$.

Wilson, C. L., and W. E. Loomis (1967). Botany 4th edition. Holt, Rinehart and Winston. New York, USA.

Wilson, J. W., D. W. Hand and M. A. Hannah (1992). Light interception and photosynthetic efficiency in some glasshouse crops. J. of Experimental Botany 43(248): 363 - 373.

Zabri, A. W. and S. W. Burrage (1997) "The effects of vapor pressure deficit (VPD) and enrichment with $\mathrm{CO}_{2}$ on water relations, photosynthesis, stomata conductance and plant growth of sweet pepper (Capsicum annum L.) grown by NFT". Acta Hort. 449(2): 561 - 567. 


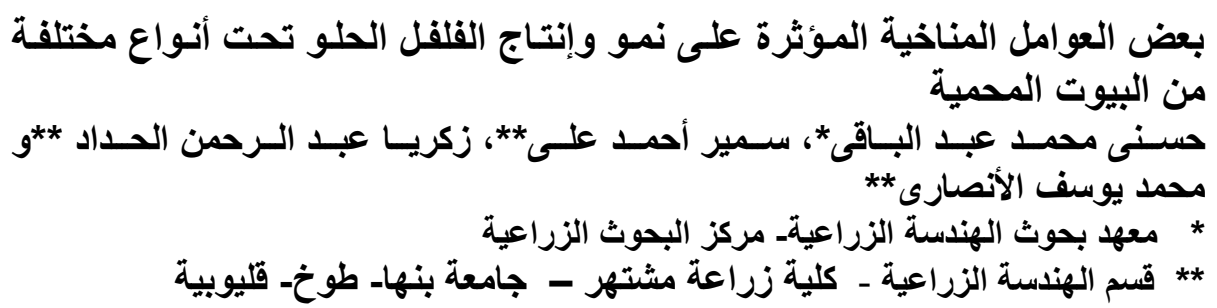

يهدف هذا البحث إلى دراسة تأثير العو امل المناخية على نمو وإنتاج الفلفل الحلو و احتباجاته

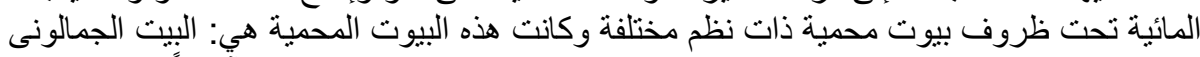

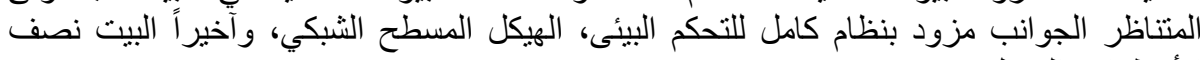

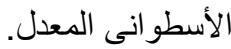

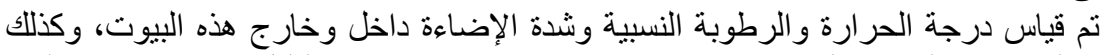

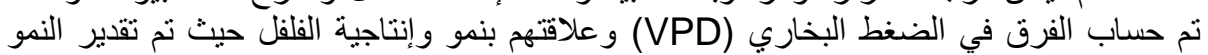

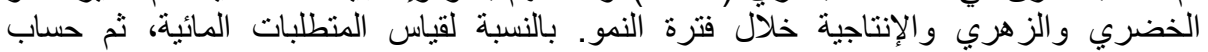

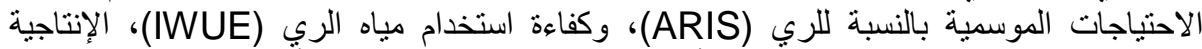

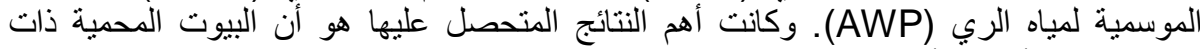

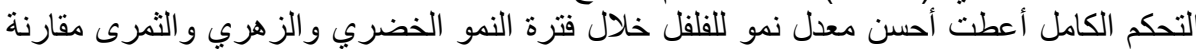
كان أعلى معدل نمو في طول النباتات (7 سم في الأسبوع) في فصل الخد الخريف للانطمة

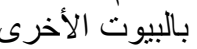

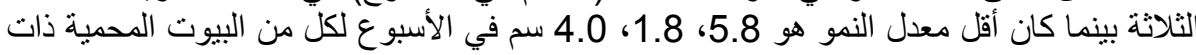

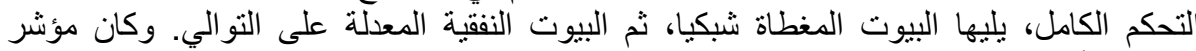

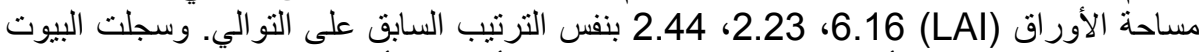

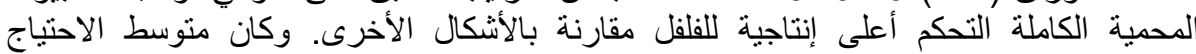

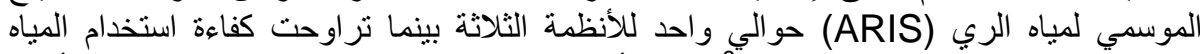

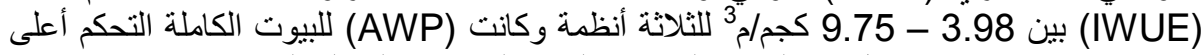
بـ 3.18، 4.08 مرة عن كل من البيوت الثبكية والنفقية المرتفعة على التو الي.

كلية الزراعة - جامعة المنصورة كلية الزراعة - جامعة الأسكندرية
قام بتحكيم البحث منطي

أ. دام صلاح مصطفى عبد البحث اللطيف أ. دأ د عبد الوهاب شُلبى قاسم 
Abd-El Baky, H.M. et al. 
J. of Soil Sciences and Agricultural Engineering, Vol. 1 (3), March, 2010 
J. of Soil Sciences and Agricultural Engineering, Vol. 1 (3): 225 - 247, 2010 
Table (1): Maximum, minimum, daylight average, nightly average, and difference between daylight and nightly averages of the air temperatures outside and inside the three different structural forms of greenhouses during the experimental period.

\begin{tabular}{|c|c|c|c|c|c|c|c|c|c|c|c|}
\hline \multicolumn{6}{|c|}{ Air Temperature Outside } & \multicolumn{6}{|c|}{ G1 (fully controlled) } \\
\hline Month & Maximum & Minimum & $\begin{array}{l}\text { Daylight } \\
\text { average }\end{array}$ & $\begin{array}{c}\text { Nightly } \\
\text { average }\end{array}$ & $\Delta \mathrm{T}$ & Month & Maximum & Minimum & $\begin{array}{l}\text { Daylight } \\
\text { average }\end{array}$ & $\begin{array}{c}\text { Nightly } \\
\text { average }\end{array}$ & $\Delta T$ \\
\hline August & 32.7 & 21.8 & 29.5 & 24.5 & 5.0 & August & 25.7 & 17.8 & 22.4 & 18.2 & 4.2 \\
\hline September & 31.1 & 20.3 & 27.9 & 22.8 & 5.1 & September & 29.3 & 18.8 & 25.3 & 19.9 & 5.4 \\
\hline October & 26.6 & 16.2 & 24.4 & 18.7 & 5.7 & October & 27.2 & 18.3 & 25.3 & 19.3 & 6.0 \\
\hline November & 23.1 & 12.8 & 20.3 & 15.4 & 4.9 & November & 26.2 & 17.0 & 24.3 & 17.8 & 6.5 \\
\hline December & 19.2 & $9 . .6$ & 16.2 & 12.1 & 4.1 & December & 25.0 & 17.6 & 22.5 & 17.9 & 4.6 \\
\hline January & 16.0 & 7.0 & 13.1 & 9.7 & 3.4 & January & 24.3 & 17.0 & 22.1 & 17.1 & 5.0 \\
\hline February & 19.9 & 10.2 & 17.0 & 12.4 & 4.6 & February & 25.7 & 16.1 & 23.5 & 17.5 & 6.0 \\
\hline March & 22.6 & 11.6 & 20.0 & 13.8 & 6.2 & March & 26.7 & 17.1 & 24.3 & 18.0 & 6.3 \\
\hline \multicolumn{6}{|c|}{ G2 (flat-roof net-house) } & \multicolumn{6}{|c|}{ G3 (modified Quonset) } \\
\hline Month & Maximum & Minimum & $\begin{array}{l}\text { Daylight } \\
\text { average }\end{array}$ & $\begin{array}{l}\text { Nightly } \\
\text { average }\end{array}$ & $\Delta \mathrm{T}$ & Month & Maximum & Minimum & $\begin{array}{l}\text { Daylight } \\
\text { average }\end{array}$ & $\begin{array}{l}\text { Nightly } \\
\text { average }\end{array}$ & $\Delta T$ \\
\hline August & 34.9 & 23.2 & 31.2 & 25.1 & 6.1 & August & 40.9 & 24.9 & 36.5 & 30.4 & 6.1 \\
\hline September & 32.8 & 19.1 & 28.8 & 22.9 & 5.9 & September & 35.9 & 20.3 & 30.2 & 25.6 & 4.6 \\
\hline October & 28.5 & 15.9 & 25.7 & 19.1 & 6.6 & October & 31.6 & 15.3 & 24.2 & 19.7 & 4.5 \\
\hline November & 24.5 & 12.1 & 21.3 & 17.1 & 4.2 & November & 26.0 & 11.0 & 21.1 & 15.1 & 6.0 \\
\hline December & 20.2 & 9.3 & 16.7 & 13.9 & 2.8 & December & 20.8 & 9.5 & 16.3 & 11.6 & 4.7 \\
\hline January & 17.1 & 7.0 & 13.7 & 11.8 & 1.9 & January & 18.4 & 6.7 & 13.7 & 9.0 & 4.7 \\
\hline February & 21.4 & 10.5 & 17.7 & 12.8 & 4.9 & February & 22.6 & 9.8 & 18.3 & 12.8 & 5.5 \\
\hline March & 23.9 & 12.0 & 20.3 & 13.9 & 6.4 & March & 25.3 & 11.2 & 21.4 & 13.4 & 8.0 \\
\hline
\end{tabular}

